In brief, he [Russe11] urges that Britain disarm, and then "if Hitler marched his troops into this country, when we were undefended, they should be welcomed like tourists and rreeted in andefendly way." Russell claims that such tactics would "take the starch" out of any invading army, reducing militarism to a simple absurdity. The theory sounds attractive. But the trouble is it runs counter to human nature. No self-respecting people would allow their homes and communities to be overrun by foreign forces without of fering some kind of indignant resistance.

Despite his rejection of Russell's basic premise, the editor did find some value in the philosopher's call for disarmament.

However, it is a good thing to have men like Russell propose honest and thoroughgoing adoption of disarmament as the only real road to peace. The impracticality of the idea for immediate application does not minimize its poteney as a means of calling attention to the inevitable connection between arms and war.

The editor's refusal to accept pacifism and disarmament as practical solutions despite his admission of the causal relationship between arms and arfare exemplifies the credibility gap which Russell and numerous other advocates of pacifism failed to bridge in their pleas for non-violent solutions to han the Republican praised the no the real worla.

As the foregoing indicates, the examination of editorial responses to Lord Russe1l's public pronouncements does provide scholars with one means, though certainly not in itself a definitive one, to mals and groups impact of his thinking on public is in in hiferent cultural, social, and in Rus car's thought by the staff of the Russell Archives would certainly enhance the value of its collection for those scholars interested in enhan the ver possible. Could it be that the time is ripe for a collective scholarly effort in such an undertaking?

Department of History

James C. Duram Wichita State University

\title{
A Midwestern Assessment of Russell's
}

\section{"Extreme Pacifism"}

An editorial entitled "It Just Wouldn't Work" published in the April 20, 1937 issue of the MoPherson (Kansas) Daily Republican presents an interesting perspective on the impact of Bertrand Russell's thought on a conservative American editor. In so doing, it brings into focus the refusal of the editor and many of his contemporaries to accept pacifism 